\title{
Professor Jan Marian Malecki (1926-2017): In MeMORIAM
}

\author{
Stefan Gąsiorowski \\ (Uniwersytet Jagielloński, Kraków) \\ e-mail: gasiorowskistefan@gmail.com
}

Key words: Kraków, Jan Marian Małecki, Kraków Academy of Economics, Jagiellonian University, Father Stanisław Musiał Award

\begin{abstract}
Jan Małecki was a historian and rector of the the Kraków Academy of Economics. While his most important research was devoted to economic history, his achievements also included works related to the grand synthesis of Polish history, methodology, source studies, bibliography, and biography. In the 1985/1986 academic year, together with two other scholars, he began an open series of lectures in the Institute of History at the Jagiellonian University entitled 'Jews in Polish History'. He was the author of a number of academic papers on the history of the Jewish community in Poland in both Polish and English. Of particular importance are his extensive source entries from Kraków customs registers concerning Jewish trade at the end of the $16^{\text {th }}$ century and start of the $17^{\text {th }}$ century, published by the Polish Academy of Arts and Sciences. Małecki also popularized Jewish issues by including them in his numerous publications on the economic history of Poland and the history of Kraków. For many years, he also promoted Jewish studies outside of the Jagiellonian University and the Kraków University of Economics and reviewed numerous works of other scholars for degrees and publishing houses. In 2016, he was granted the Father Stanisław Musiał Award for his work on the history and culture of the Jewish community in Poland.
\end{abstract}

Jan Marian Małecki was born on $8^{\text {th }}$ December 1926 in Sosnowiec. Three years later, he and his family permanently relocated to Kraków. During the German occupation, he received an underground education, and was forced to take up paid work at the PZU public insurance company. Shortly after the Second World War, and after receiving his high school certificate, he began studying history at the Faculty of Humanities of the Jagiellonian University, where lectures were being given by many outstanding professors. One such lecturer was a historian of the modern era, Prof. Władysław Konopczyński, who advised Małecki when he was writing his master's thesis (defended in 1950) on the political history of the Polish-Lithuanian Commonwealth in the first half of the $17^{\text {th }}$ century. After his studies, he received a mandatory work assignment from the Faculty Commission at a vocational school in Elbląg, where he spent four years. During this period, he wrote articles on the history of Pomerania, Warmia, and Mazury, concentrating on regional history and the socio-economic history of Polish cities in the $16^{\text {th }}$ and $17^{\text {th }}$ centuries. 
After returning to Kraków in 1954, Małecki was hired at the Institute of History of the Polish Academy of Sciences, and shortly after at the Higher School of Economics (now the Kraków University of Economics) at the Department of Economic History. He was associated with the latter throughout his entire professional life. It is also worth mentioning that, aside from serving as the chair of this department, he became vicerector of the Kraków Academy of Economics in 1975, and later its rector-elected in the first fully democratic elections — during the difficult period of 1981-1984. ${ }^{1}$

Prof. Małecki worked mostly on economic history, but his achievements also include works related to the grand synthesis of Polish history, methodology, source studies, bibliography, and biography. ${ }^{2}$ Of his many publications some of the most important include Studia nad rynkiem regionalnym Krakowa $w$ XVI wieku [Studies on the regional market of Kraków in the $16^{\text {th }}$ century], his doctoral dissertation defended $24^{\text {th }}$ February 1962 and published in Warsaw in 1963, Zwiąki handlowe miast polskich z Gdańskiem w XVI wieku i pierwszej połowie XVII wieku [Trade Relations of Polish Cities with Gdańsk in the $16^{\text {th }}$ Century and the First Half of the $17^{\text {th }}$ Century] his postdoctoral dissertation, published in Wrocław in 1968, and two monumental volumes of Dzieje Krakowa [The History of Kraków] covering the period from the $16^{\text {th }}$ century to the beginning of the $20^{\text {th }}$ century, which he completed with the assistance of Janina Bieniarzówna. ${ }^{3}$ For many years, Prof. Małecki edited the academic journal, Rocznik Krakowski [The Kraków Yearbook], as well as periodicals associated with Kraków, including Kraków dawniej i dziś [Kraków Then and Now], Rola Krakowa w Dziejach Narodu [The Role of Kraków in the History of the Nation], and Biblioteka Krakowska [Kraków Library]. He was also a member of the Polish Academy of Arts and Sciences and the Council of the Historical Museum of Kraków, and he help both ordinary and honorary membership of the board of the Society of Friends of History and Monuments of Kraków. In 2000, he received an honorary doctorate from the Kraków University of Economics. Furthermore, in 2006, the year of his $80^{\text {th }}$ birthday, he was granted the Honoris Gratia award for his work on Kraków by Jacek Majchrowski, the city's mayor. In recent years he became known particularly for his book Historia Krakowa dla każdego [A History of Kraków for Everyone], which was named Kraków Book of the Month during 2007. ${ }^{4}$ On $10^{\text {th }}$ January 2013, Prof. Małecki's doctorate was ceremonially renewed in the auditorium of Collegium Maius at the Jagiellonian University.

It is not commonly known that Prof. Jan Malecki took part in elite academic seminars organized by Pope John Paul II in Castel Gandolfo, where the most important problems of the time were discussed from a historical perspective. At the last of these seminars in 2003, the professor gave a talk on "Time in Historical Research and the Responsibility of Historians." 5

1 Professor Jan Marian Małecki, in: Professor profiles. Department of Economic and Social History, Kraków University of Economics, http://khgis.uek.krakow.pl/?pid=pages\&id=32 [accessed 28 June 2017]; Purchla, Rektor Jan Małecki, http://khgis.uek.krakow.pl/images/upload/laudacja_profjpurchla_02_01_2008. pdf [accessed: 28 Juny 2017]; unpaginated; Purchla 2016: 9-13; Małecki 2016: 15-17.

2 A full list of his works can be found in Bibliografia prac Profesora Jana M. Mateckiego, in: Bibliografia prac Profesora Jana M. Małeckiego wydana na 90. urodziny: 22-75.

3 Bieniarzówna, Małecki 1979; Bieniarzówna, Małecki 1984.

4 Małecki 2007; Małecki 2008.

5 Purchla, Rektor Jan Małecki, unpaginated. 
In his research on Polish economic history, Prof. Małecki could not ignore Jewish themes. As he himself recalled, even before the political transformation of 1989 he had been sharing his deep historical knowledge with his students on topics such as the economic development of the Second Polish Republic and on less researched issues such as those of national minorities. Thus, alongside Profs. Jerzy Wyrozumski and Tomasz Gąsowski, Prof. Małecki was among the pioneers in teaching about the history of Polish Jews. He gave lectures on the subject not only at the University of Economics, but also at the Jagiellonian University. In the winter semester of 1985/1986, he began an open series of lectures at the Jagiellonian University Institute of History entitled Ludność żydowska $w$ dziejach Polski [Jews in Polish History], together with Wyrozumski and Gąsowski. For many years, Wyrozumski lectured on the Middle Ages, Prof. Małecki on the modern era, and Dr. Gąsowski on the 19th century. These lectures, which took place in Room 56 of Collegium Novum, enjoyed great popularity among students of various disciplines.

As early as the 1980 s, Prof. Małecki was also among the first Polish scholars to engage in dialog with scholars from Israel. This led to his participation in lectures at academic conferences on Jewish issues both in Poland and abroad. The first such conference, entitled Autonomia Żydów w Rzeczypospolitej szlacheckiej [The Autonomy of Jews in the Royal Commonwealth] took place in Kraków in September 1986, and saw the inauguration of the UJ Interdepartmental Research Centre for Jewish History and Culture in Poland (now the Institute of Jewish Studies within the UJ Faculty of History). The second took place in Jerusalem in 1988. These are considered by many to have been a watershed in the building of positive Polish-Jewish relations, and the beginning of cooperative study of a common past. ${ }^{6}$

Małecki's research in this field over many years resulted in several academic papers on the history of the Jewish community in Poland. Among them are $\dot{Z} y d z i w$ życiu gospodarczym Krakowa $w X V I-X V I I$ [Jews in the Economic Life of Kraków in the $16^{\text {th }}$ and $17^{\text {th }}$ Century]; Żydzi krakowscy w XIX wieku [Kraków Jews in the 19th Century]; Ludność zydowska w Galicji w dobie autonomii [The Jewish Population in Galicia in the Era of Autonomy]; and Zamieszki w Krakowie w kwietniu 1918 r. Pogrom czy rozruchy głodowe? [Riots in Kraków in April 1918. Pogrom or Hunger Riots?]. These have been published in various collections and academic journals in both Polish and English. ${ }^{7}$ Of particular importance are his extensive source entries from Kraków customs registers concerning Jewish trade at the end of the $16^{\text {th }}$ century and start of the the $17^{\text {th }}$ century, published with the assistance of Elżbieta Szlufik of the Polish Academy of Arts and Sciences. ${ }^{8}$ Małecki also popularized Jewish issues by including them in his numerous publications on the economic history of Poland and the history of Kraków.

\footnotetext{
${ }^{6}$ Małecki 1991: 214-225; Małecki 1993: 267-281.

${ }^{7}$ Małecki 1988 [printed 1989]: 14-18; Małecki 1992 [printed 1993]: 245-257; Małecki 1994: 231-245; Małecki 1997: 85-96; Małecki 1998: 143-153; Małecki 2002: 53-56.

${ }^{8}$ Handel żydowski w Krakowie w końcu XVI i w XVII wieku. Wypisy z krakowskich rejestrów celnych $z$ lat 1593-1683. Jewish Trade in Cracow at the End of the XVI Century and in the XVII. Selected Records from Cracow Customs Registres 1593-1683, compiled by Jan M. Małecki, assisted by Elżbieta Szlufik, Kraków 1995: Polish Academy of Arts and Sciences, pp. 284, unpaginated 2. Polish Academy of Arts and Sciences, Jagiellonian University in Kraków, Israel Academy of Sciences and Humanities, Hebrew University of Jerusalem.
} 
For many years, Jan M. Małecki also promoted Jewish Studies outside of the Jagiellonian University and the Kraków University of Economics. In 1995 he was appointed the first chairperson of the newly established Interdepartmental Commission for Jewish History and Culture in Poland in the Polish Academy of Arts and Sciences, whose purpose was to propagate Jewish history and culture and to support related publications and conferences. He served in this capacity for thirteen years. Małecki was a consultant for the exhibition Świat przed katastrofą. Żydzi krakowscy $w$ dwudziestoleciu międzywojennym [A World before Catastrophe: Kraków Jews during the Interwar Period], organized by the International Culture Centre in Kraków. The exhibition at the ICC, ran from June to October 2007. Małecki was also scientific editor of the exhibition's catalog. ${ }^{9}$

Another important aspect of Prof. Małecki's career was his behind-the-scenes work which required erudition in Jewish studies and — above all — a little free time: reviewing the work of other scholars for degrees and publishing houses. He did this both willingly and with great diligence, despite the constant demands of his other professional activities. For example, he was the reviewer of my postdoctoral dissertation on the history of the Karaites in the former Commonwealth. ${ }^{10}$

Prof. Małecki was always willing share his knowledge with others; recently this generosity extended to his donation of his collection of Judaica to the library of the the UJ Institute of Jewish Studies. He was an open, modest, and diligent man. On 4 March 2016, he was granted the Father Stanisław Musiał Award for his work on the history and culture of the Jewish community in Poland. During the ceremony, he was lauded by UJ Rector, Prof. Wojciech Nowak.

Prof. Jan Małecki lost his long battle with illness on $12^{\text {th }}$ June 2017, and was buried at the Batowicki Cemetery in Kraków.

Translated by Jack Ramsey Zagorski

\section{BIBLIOGRAPHY}

\section{Printed sources}

Handel żydowski w Krakowie w końcu XVI $i$ w XVII wieku. Wypisy z krakowskich rejestrów celnych $z$ lat 1593-1683. Jewish Trade in Cracow at the End of the XVI Century and in the XVII. Selected Records from Cracow Customs Registers 1593-1683, compiled by J.M. Małecki, assisted by E. Szlufik, Kraków 1995 Polish Academy of Arts and Sciences, pp. 284, backmatter 2. Polish Academy of Arts and Sciences, Jagiellonian University in Kraków, Israel Academy of Sciences and Humanities, Hebrew University of Jerusalem.

\section{Secondary literature}

Bibliografia prac Profesora Jana M. Mateckiego wydana na 90. urodziny (2016), J. Purchla (ed.), Kraków: Księgarnia Akademicka, p. 75, unpaginated 1, il.

9 Świat przed katastrofą. Żydzi krakowscy w dwudziestoleciu międzywojennym. A world before a catastrophe. Krakow's Jews between the wars, scientific ed. Jan M. Małecki, Kraków 2007 International Culture Centre, pp. 175, unpaginated 2, il.

${ }^{10}$ Gąsiorowski 2008. 
Bieniarzówna, J., Małecki, J.M. (1979), Dzieje Krakowa, T. 3: Kraków w latach 1796-1918, J. Bieniarzówna, J.M. Małecki, J. Mitkowski (eds.), Kraków: Wydawnictwo Literackie, p. 435, unpaginated 1 , il.

Bieniarzówna, J., Małecki, J.M. (1984), Dzieje Krakowa, T. 2: Kraków w wiekach XVI-XVIII, J. Bieniarzówna, J.M. Małecki, J. Mitkowski (eds.), Kraków: Wydawnictwo Literackie, p. 666, unpaginated 5 , il.

Gąsiorowski, S. (2008), Karaimi w Koronie i na Litwie w XV-XVIII wieku, Kraków-Budapest: Wydawnictwo Austeria, p. 598, il.

Małecki, J.M. (1988) [printed 1989], Żydzi w życiu gospodarczym Krakowa w XVI i pierwszej połowie XVII wieku, Krzysztofory. Zeszyty Naukowe Muzeum Historycznego Miasta Krakowa, vol. 15: 14-18.

Małecki, J.M. (1991), Handel żydowski u schyłku XVI i w 1 połowie XVII w. w świetle krakowskich rejestrów celnych, in: $\dot{Z} y d z i w$ dawnej Rzeczypospolitej. Materiaty z konferencji „Autonomia $\dot{Z} y$ dów w Rzeczypospolitej Szlacheckiej”. Międzywydziałowy Zakład Historii i Kultury Żydów w Polsce Uniwersytet Jagielloński, 22-26 IX 1986 r., scientific ed. A. Link-Lenczowski, T. Polański, Wrocław: 214-225.

Małecki, J.M. (1992) [printed 1993], Zamieszki w Krakowie w kwietniu 1918 r. Pogrom czy rozruchy głodowe?, in: A.K. Paluch (ed.), The Jews in Poland. Volume I, Kraków: 245-257.

Małecki, J.M. (1993), Jewish Trade at the End of the Sixteenth Century and in the First Half of the Seventeenth Century, in: A. Polonsky, J. Basista, A. Link-Lenczowski (eds.), The Jews in Old Poland 1000-1795, London-New York: 267-281.

Małecki, J.M. (1994), Ludność żydowska w Galicji w dobie autonomii (1867-1914), in: A. Zeliaś (ed.), O zwiazkach demografii, statystyki i ekonometrii. Księga jubileuszowa dla uczczenia 50-lecia pracy naukowo-dydaktycznej Profesora Kazimierza Zająca, Kraków: 231-245.

Małecki, J.M. (1997), Cracow Jews in the $19^{\text {th }}$ Century: Leaving the Ghetto, Acta Poloniae Historica, vol. 76: 85-96.

Małecki, J.M. (1998), Żydzi krakowscy w XIX wieku: wyjście z getta, in: M. Bogucka [et al.] (ed.), Wspólnoty lokalne $i$ środowiskowe $w$ miastach i miasteczkach ziem polskich pod zaborami i po uzyskaniu niepodległości, Torun: 143-153.

Małecki, J.M. (2002), Udział Żydów w organach samorządowych większych miast galicyjskich na początku XX wieku, in: K. Ślusarek (ed.), Polska i Polacy w XIX-XX wieku. Studia ofiarowane Profesorowi Mariuszowi Kulczykowskiemu w 70 rocznicę Jego urodzin, Kraków: 53-56.

Małecki, J.M. (2007), Historia Krakowa dla każdego, Kraków: Wydawnictwo Literackie.

Małecki, J.M. (2008), A History of Kraków for Everyone, trans. by J. Taylor-Kucia, Kraków: Wydawnictwo Literackie.

Małecki, J.M. (2016), Przemówienie na uroczystym posiedzeniu Senatu Uniwersytetu Jagiellońskiego, 10 stycznia 2013 roku z okazji odnowienia doktoratu, in: J. Purchla (ed.), Bibliografia prac Profesora Jana M. Małeckiego wydana na 90. urodziny, Kraków: 15-17.

Purchla, J. (2016), Laudacja wygłoszona na uroczystości odnowienia doktoratu Profesora Jana M. Małeckiego w Uniwersytecie Jagiellońskim, 10 stycznia 2013 roku, in: J. Purchla (ed.), Bibliografia prac Profesora Jana M. Małeckiego wydana na 90. urodziny, Kraków: 9-13.

Świat przed katastrofa. Żydzi krakowscy w dwudziestoleciu międzywojennym. A world before a catastrophe. Krakow's Jews between the wars, scientific ed. by Jan M. Małecki, Kraków 2007 International Culture Centre, pp. 175, unpaginated 2, il.

\section{Internet sources}

Professor Jan Marian Małecki, in: Professor profiles. Department of Economic and Social History, Kraków University of Economics, http://khgis.uek.krakow.pl/?pid=pages\&id=32 [accessed 28 June 2017].

Purchla J., Rektor Jan Matecki. Laudation during the $80^{\text {th }}$ birthday of Professor Jan M. Małecki, unpaginated, http://khgis.uek.krakow.pl/images/upload/laudacja_profjpurchla_02_01_2008.pdf[accessed 28 July 2017]. 